\title{
PENGARUH LAMA PERENDAMAN DAN KONSENTRASI ASAP CAIR TERHADAP PENILAIAN ORGANOLEPTIK DAN KIMIA POKEA (Batissa violacea var. celebensis, von Martens 1897) ASAP
}

\author{
Prilya Zhatrawati Mentang*, Moh. Nuh Ibrahim, Kobajashi T. Isamu \\ Jurusan Teknologi Hasil Perikanan Fakultas Perikanan dan Ilmu Kelautan Universitas Halu Oleo, \\ Jalan H.E.A Mokodompit Kampus Bumi Tridharma Anduonohu, Kendari 93232 Sulawesi Tenggara \\ Telepon +628394785000 \\ *Korespondensi: prilyazhatrawatimentang@gmail.com \\ Diterima: 29 Januari 2019/Disetujui: 16 April 2019
}

\begin{abstract}
Cara sitasi: Mentang PZ, Ibrahim MN, Ishamu KT. 2019. Pengaruh lama perendaman dan konsentrasi asap cair terhadap penilaian organoleptik dan kimia pokea (Batissa violacea var. celebensis, von Martens 1897) asap. Jurnal Fish Protech. 2(1):110-118.
\end{abstract}

\begin{abstract}
Abstrak
Penelitian ini bertujuan Untuk mengetahui pengaruh lama perendaman asap cair, konsentrasi asap cair interaksi antara lama perendaman dan konsentrasi asap cair terhadap mutu pokea asap.Penelitian ini menggunakan Rancangan Acak Lengkap Faktorial (RALF) yang terdiri dari dua faktor. Faktor pertama yaitu waktu perendaman $(5,10,15$ menit), faktor kedua yaitu konsentrasi asap cair $(2 \%, 4 \%, 6 \%)$ dengan tiga kali ulangan. Pokea asapterhadap interaksi lama perendaman dan konsentrasi asap cair terhadap organoleptikrupa, bau, tekstur, rasa, kadar air dan kadar protein berpengaruh sangat nyata. Kadar benzo(a)pyrene pada T3N1 sebesar 2,47 mg/kg, T3N2 sebesar $5,46 \mathrm{mg} / \mathrm{kg}$ dan T3N3 sebesar 3,84 mg/kg. Rerata organoleptik rupa diperoleh nilai tertinggi pada T2N2 sebesar 4 (suka), bau pada perlakuan T2N3 sebesar 4 (suka), rasa pada perlakuan T2N3 sebesar 3 (agak suka), tekstur pada perlakuan T2N3 sebesar 4 (suka), kadar air pada perlakuan T3N1 sebesar 9,91\% dan kadar protein pada perlakuan T2N3 sebesar 45,69\%.
\end{abstract}

Kata kunci: Pokea, asap cair, kadar air, kadar protein, organoleptik

\section{EFFECT OF SOAKING DURATION AND LIQUID SMOKE CONCENTRATION ON CHEMICAL AND ORGANOLEPTIC ASSESSMENT POKEA(Batissa violacea var. Celebensis, von Martens 1897) SMOKED}

\begin{abstract}
The aims of this study was to determine the effect of liquid smoke soaking time, liquid smoke concentration and interaction between soaking time and liquid smoke concentration on the quality of smoke pokea. This research used a Factorial Completely Randomized Design (FCRD) consisting of two factors. The first factor is soaking time $(5,10,15$ minutes), the second factor is the concentration of liquid smoke $(2 \%, 4 \%$, $6 \%$ ) with three replications. Smokedpokea for interaction of soaking time and liquid smoke concentration on organoleptic appearance, odor, texture, taste, water content and protein content had a very significant effect. The level of benzo(a)pyrene on T3N1 was $2.47 \mathrm{mg} / \mathrm{kg}$, T3N2 was $5.46 \mathrm{mg} / \mathrm{kg}$ and T3N3 was $3.84 \mathrm{mg} / \mathrm{kg}$. The mean organoleptic
\end{abstract}


obtained the highest value on T2N2 of 4 (likes), odor at T2N3 of 4 (likes), taste on T2N3 of 3 (rather like), texture on T2N3 of 4 (likes), water content on T3N1 was $9.91 \%$ and protein content in $\mathrm{T} 2 \mathrm{~N} 3$ was $45.69 \%$.

Key words: Pokea clam, liquid smoke, moisture content, protein content, organoleptic,

\section{PENDAHULUAN}

Provinsi Sulawesi Tenggara memiliki beberapa sungai besar maupun sungai kecil yang sangat potensial untuk kebutuhan air bersih, irigasi, pembangkit listrik, dan untuk berbagai kebutuhan lainnya. Sungai Pohara merupakan salah satu sungai yang terdapat di Sulawesi Tenggara. Di dalam suatu sistem Daerah Aliran Sungai, sungai yang berfungsi sebagai wadah pengaliran air selalu berada di posisi paling rendah dalam landskap bumi, sehingga kondisi sungai tidak dapat dipisahkan dari kondisi Daerah Aliran Sungai (PP 38 Tahun 2011).

Jenis kerang lain yang telah dikonsumsi oleh masyarakat adalah kerang pokea(Batissa violacea celebensis Marten 1897). Kerang ini diduga endemik karena hanyaditemukan di Sungai Pohara Kabupaten Konawe Sulawesi Tenggara sekitar $25 \mathrm{~km}$ ke arahmuara pada kedalaman 1-9 meter (Bahtiar 2005). Kerang pokea merupakan moluska airtawar dari Famili Corbiculidae yang memiliki cangkang berwarna coklat tua hingga ungukehitam-hitaman, bentuknya sedikit pipih dan membulat.Kerang pokea memiliki kandungan nutrisi, yang baik dan kandungan air yang tinggi sehingga tidak bisa disimpan dalam waktu yang lama. Untuk itu, diperlukan pengolahan dan pengawetan. Salah satunya adalah pengasapan.

Pengasapan adalah salah satu metode pengawetan yang merupakan pemanasan (smoking).Asap cair merupakan senyawa-senyawa yang menguap secara simultan dari reaktor panas melalui teknik pirolisis (penguraian dengan panas) dan berkondensasi pada sistem pendingin. Pengolahan ikan menggunakan asap cair memiliki beberapa kelebihan yaitu mudah diterapkan atau praktis penggunaannya, lebih efesien dalam penggunaan bahan pengasap, polusi lingkungan dapat diperkecil, dan yang paling penting senyawa karsinogen yang terbentuk dapat diminimalkan. Asap cair berdasarkankegunaannya dapat diaplikasikan ke berbagai bahan makanan tak terkecuali ikan yang akan diolah (Ayudiarti dan Sari, 2010).

Metode yang digunakan adalah dengan penerapan asap cair karena memiliki kelebihan-kelebihan yang tidak dimiliki pengasapan tradisional yaitu mudah diaplikasikan dalam konsentrasi yang rendah sehingga lebih hemat. Selain komponen karsinogen dapat dipisahkan, efek antioksidan dan antimikrobanya juga lebih menonjol (Clucas and Ward,1996).

Asap cair merupakan hasil kondensasi dari kayu yang mengandung fenoll, asam organik,dan karbonil. Ketiga senyawa tersebut berperan dalam memperbaiki sifat produkikan asap, antimikroba dan antioksidan. Senyawa karbonil dalam asap cair,berperan dalam pembentukan karakteristik ikan asap yang dihasilkan. Reaksimaillard antara karbonil dengan lemak menghasilkan aroma khas ikan asap.Sedangkan dengan protein, menghasilkan karakteristik sensori khas ikan asapmeliputi kenampakan, tekstur dan warna (Halim et al., 2005; Varlet et al, 2007). 
Tujuan dari penelitian ini adalah Untuk mengetahui pengaruh lama perendaman asap cair, konsentrasi asap cair interaksi antara lama perendaman dan konsentrasi asap cair terhadap mutu pokea asap.

\section{BAHAN DAN METODE}

\section{Bahan dan Alat}

Bahan yang akan digunakan terdiri atas bahan utama dan bahan pendukung. Bahan utama adalah daging kerang pokea segar dan asap cair. Bahan kimia dan pereaksi yang digunakan adalah petroleum eter, $\mathrm{H}_{2} \mathrm{SO}_{4}, \mathrm{NaOH}$, etanol, $\mathrm{HCl}, \mathrm{CuSO}_{4}$, indikator metil merah, indikator metil biru, asam oksalat, aquades, dan pereaksi anthrone.

\section{Tahapan Penelitian}

\section{Penyiapan Bahan}

Bahan mentah $2 \mathrm{~kg}$, dalam pengolahan ini digunakan bahan mentah pokea. Selanjutnya pokea dicuci dengan air mengalir, selanjutnya pemisahan daging pokea dari cangkang. Penyediaan wadah untuk perendaman.

\section{Perendaman dalam Asap Cair}

Pokea dimasukkan ke wadah yang telah berisi larutan asap cair. Pengasapan dilakukan tiga perlakuan. Pertama perendaman dengan konsentrasi asap cair sebanyak 2\%, 4\% dan $6 \%$ dari banyaknya air yang digunakan sebanyak $500 \mathrm{ml}$ dengan lama perendaman 5 menit, tahap kedua konsentrasi asap cair sebanyak 2\%, 4\% dan $6 \%$ dari banyaknya air yang digunakan sebanyak $500 \mathrm{ml}$ dengan lama perendaman 10 menit, dan perlakuan ketiga konsentrasi asap cair yang sama dan banyaknya air yang digunakan sebanyak $500 \mathrm{ml}$ dengan lama perendaman 15 menit.

\section{Penjemuran}

Setelah perendaman, pokea asap ditiriskan. Kemudian daging pokea di simpan pada talang, dijemur dengan sinar matahari selama 2 jam hingga daging pokea benar-benar kering selama 7 hari.

\section{Penilaian Organoleptik}

Untuk menentukan pokea asap yang paling disukai oleh panelis dari setiap perlakuan, dilakukan penilaian organoleptik terhadap pokea asap yang meliputi rupa, bau, tekstur dan rasa dengan menggunakan skala hedonik. Pengujian ini berdasarkan pada pemberian skor panelis terhadap rupa, tekstur, bau dan rasa. Pengujian menggunakan 25 orang panelis. Skor penilaian yang diberikan berdasarkan kriteria uji hedonik.

\section{Analisis Nilai Kimia}

Analisis nilai kimia pokea asap yang paling disukai oleh panelis selanjutnya dianalisis kadar air, kadar protein dan senyawa PAH.

\section{Rancangan Penelitian}

Rancangan percobaan yang digunakan adalah Rancangan Acak Lengkap Faktorial (RALF), sebagai faktor perlakuan pertama adalah waktu perendaman yang terdiri dari 3 perlakuan yaitu T1 (5 menit), T2 (10 menit) dan T3 (15 menit). Faktor perlakuan yang kedua adalah konsentrasi asap cair yang terdiri dari $\mathrm{N} 1 \quad(2 \%), \quad \mathrm{N} 2 \quad(4 \%), \quad$ dan N3 (6\%).Masing-masing perlakuan dilakukan 3 kali ulangan, sehingga diperoleh jumlah satuan percobaan sebanyak 27 unit.

\section{Analisis Data}

Data diperoleh dari hasil penilaian organoleptik kesukaan panelis terhadap variasi penambahan 
konsentrasi asap cair dan lama perendaman terhadap pokea asap. Data kemudian dianalisis dengan menggunakan analisis sidik ragam (ANOVA). Bila dalam analisis ragam menunjukkan perlakuan yang berpengaruh nyata maka dilanjutkan dengan uji Duncan pada taraf kepercayaan $95 \%(\alpha=0,05)$.

\section{HASIL DAN PEMBAHASAN}

\section{Uji Organoleptik}

Hasil uji organoleptik interaksi lama perendaman dan konsentrasi asap cair terhadap rupa, bau, tesktur, rasa pada pengolahan pokea asap disajikan pada Tabel 1.

Tabel 1. Nilai pengujian organoleptik interaksi lama perendaman dan konsentrasi pokea asap cair

\begin{tabular}{llllllllll}
\hline \multirow{2}{*}{ Parameter } & \multicolumn{10}{c}{ Interaksi Perlakuan } \\
\cline { 2 - 9 } & T1N1 & T1N2 & T1N3 & T2N1 & T2N2 & T2N3 & T3N1 & T3N2 & T3N3 \\
\hline Rupa & 3,21 & 3,56 & 3,42 & 3,13 & 3,70 & 3,69 & 3,58 & 3,35 & 3,65 \\
Bau & 3,08 & 3,02 & 3,32 & 2,96 & 3,50 & 3,54 & 3,52 & 3,50 & 3,53 \\
Tekstur & 3,56 & 3,58 & 3,37 & 3,69 & 3,52 & 3,94 & 3,52 & 3,60 & 3,72 \\
Rasa & 2,88 & 2,74 & 2,78 & 3,14 & 3,17 & 3,35 & 3,05 & 3,00 & 3,24 \\
\hline
\end{tabular}

\section{Rupa}

Perlakuan interaksi lama perendaman dan konsentrasi asap cair terhadap penilaian nilai rupa pokea asap diperoleh penilaian tertinggi pada perlakuan T2N2 (perendaman 10 menit dan konsentrasi 4\%) dengan nilai sebesar 3,70 (suka) dan hasil penilaian nilai rupa terendah pada perlakuan T2N1 (perendaman 10 menit dan konsentrasi 2\%) dengan nilai sebesar 3,13 (cukup suka) sebagaimana pada Tabel 1.

T2N2 $\begin{gathered}\text { Daging pokea pada perlakuan } \\ \text { (perendaman } 10 \text { menit }\end{gathered}$ konsentrasi $4 \%$ ) dan perlakuan $\mathrm{T} 2 \mathrm{~N} 1$ (perendaman 10 menit dan konsentrasi 2\%) menghasilkan warna coklat yang tidak jauh berbeda. Hal ini diduga akibat adanya proses penjemuran dengan menggunakan panas matahari yang cukup lama, sehingga menyebabkan terjadinya proses pencoklatan. Hal ini sesuai dengan pendapat Darmadji (2006), bahwa warna coklat terjadi karena hasil reaksi maillard yang di pengaruhi oleh beberapa faktor seperti kandungan gula reduksi, waktu serta temperatur pemanasan.

Bau

Perlakuan interaksi lama perendaman dan konsentrasi asap cair terhadap penilaian organoleptik bau pokea asap diperoleh penilaian tertinggi pada perlakuan T2N3 (perendaman 10 menit dan konsentrasi 6\%) dengan nilai rerata sebesar 3,54 (suka) dan hasil penilaian organoleptik bau terendah pada perlakuan T2N1 (perendaman 10 menit dan konsentrasi 2\%) dengan nilai rerata sebesar 2,96 (cukup suka) sebagaimana pada Tabel 1.

Daging pokea pada perlakuan T2N3 (perendaman 10 menit dan konsentrasi 6\%) dan perlakuan $\mathrm{T} 2 \mathrm{~N} 1$ (perendaman 10 menit dan konsentrasi 2\%) menghasilkan bau khas asap. Hal ini diduga karena jenis asap cair yang di gunakan sama sehingga senyawa volatil seperti fenol yang menghasilkan bau asap yang khas pada produk asapan tidak jauh berbeda meskipun konsentrasi berbeda setiap perlakuan. Hal ini sesuai pendapat Girard (1992), menyatakan bahwa aroma asap yang 
terbentuk sebagian besar dipengaruhi oleh adanya senyawa fenol (siringol) dan karbonil serta sebagian kecil juga dipengaruhi oleh asam.

\section{Tekstur}

Perlakuan penambahan lama perendaman dan konsentrasi asap cair terhadap penilaian organoleptik tekstur pokea asap diperoleh penilaian tertinggi pada perlakuan T2N3 (perendaman 10 menit dan konsentrasi 6\%) dengan nilai rerata sebesar 3,94 (suka) dan hasil penilaian organoleptik tekstur terendah pada perlakuan T1N2 (perendaman 5 menit dan konsentrasi 4\%) dengan nilai rerata sebesar 2,37 (tidak suka) sebagaimana pada Tabel 1.

Daging pokea pada perlakuan T2N3 (perendaman 10 menit dan konsentrasi 6\%) dan perlakuan T1N3 (perendaman 5 menit dan konsentrasi 6\%) menghasilkan tekstur yang agak keras. Hal ini diduga karena tingkat kekeringan produk dan kadar air produk, dimana semakin tinggi kadar air semakin rendah nilai tekstur produk. Hal ini sesuai pendapat Fellow (2000), tekstur makanan kebanyakan ditentukan oleh kandungan air yang terdapat pada produk tersebut.

\section{Rasa}

Perlakuan interaksi lama perendaman dan konsentrasi asap cair terhadap penilaian organoleptik rasa pokea asap diperoleh penilaian tertinggi pada perlakuan T2N3 (perendaman 10 menit dan konsentrasi 6\%) dengan nilai rerata sebesar 3,35 (cukup suka) dan hasil penilaian organoleptik rasa terendah pada perlakuan T1N2 (perendaman 5 menit dan konsentrasi 4\%) dengan nilai rerata sebesar 2,74 (cukup suka) sebagaimana pada Tabel 1.

Nilai rasa pokea asap secara organoleptik oleh panelis masingmasing perlakuan memiliki nilai rasa yang berbeda yaitu rasa pokea asap dipengaruhi oleh komponen yang dihasilkan melalui pengasapan asap cair dengan lama perendaman berbeda menghasilkan rasa yang berbeda sehingga semakin lama waktu perendaman, maka akan semakin terbentuk rasa asap pada pokea asap. Hal ini sesuai dengan pendapat Goulas (2005), bahwa rasa dipengaruhi oleh beberapa faktor yaitu senyawa kimia, suhu, konsentrasi dan interaksi dengan komponen rasa lainnya.

\section{Uji Nilai Gizi}

Hasilujinilai gizi lama perendaman dan konsentrasi asap cair terhadap kadar air dan kadar protein pada pengolahan pokea asap disajikan pada Tabel 2.

Tabel 2. Nilai gizi pokea asap cair

\begin{tabular}{|c|c|c|c|c|}
\hline Perlakuan & Kadar Air (\%) & $\mathrm{DMRT}_{0,05}$ & $\begin{array}{l}\text { Kadar Protein } \\
(\%)\end{array}$ & $\mathrm{DMRT}_{0,05}$ \\
\hline $\mathrm{T} 1$ & $9,34^{\mathrm{a}}$ & & $37,91^{b}$ & \\
\hline $\mathrm{T} 2$ & $9,39^{\mathrm{a}}$ & $2=0,22$ & $43,38^{\mathrm{a}}$ & $2=1,37$ \\
\hline $\mathrm{T} 3$ & $9,31^{\mathrm{a}}$ & $3=0,23$ & $37,87^{\mathrm{b}}$ & $3=1,43$ \\
\hline N1 & $9,53^{\mathrm{a}}$ & & $37,43^{b}$ & \\
\hline $\mathrm{N} 2$ & $9,29^{b}$ & $2=0,22$ & $40,46^{\mathrm{a}}$ & $2=1,43$ \\
\hline N3 & $9,22^{\mathrm{b}}$ & $3=0,23$ & $41,27^{\mathrm{a}}$ & $3=1,37$ \\
\hline
\end{tabular}

Keterangan: Angka-angka yang diikuti oleh notasi huruf yang sama menunjukkan pengaruh tidak nyata, pada taraf kepercayaan $95 \%(\alpha=0,05)$ 
Hasil uji nilai gizi interaksi lama perendaman dan konsentrasi asap cair terhadap kadar air dan kadar protein pada pengolahan pokea asap disajikan pada Tabel 3.

Tabel 3. Nilai gizi interaksi lama perendaman dan konsentrasi asap cair pokea asap

\begin{tabular}{|c|c|c|c|c|c|c|c|c|c|}
\hline \multirow{2}{*}{ Parameter } & \multicolumn{9}{|c|}{ Interaksi Perlakuan } \\
\hline & T1N1 & T1N2 & T1N3 & $\mathrm{T} 2 \mathrm{~N} 1$ & $\mathrm{~T} 2 \mathrm{~N} 2$ & $\mathrm{~T} 2 \mathrm{~N} 3$ & T3N1 & $\mathrm{T} 3 \mathrm{~N} 2$ & $\mathrm{~T} 3 \mathrm{~N} 3$ \\
\hline $\begin{array}{l}\text { Kadar air } \\
(\%)\end{array}$ & $9,21^{\mathrm{b}}$ & $9,34^{\mathrm{b}}$ & $9,46^{\mathrm{b}}$ & $9,46^{\mathrm{b}}$ & $9,54^{\mathrm{ab}}$ & $9,15^{\mathrm{bc}}$ & $9,91^{\mathrm{a}}$ & $8,79^{c}$ & $9,25^{\mathrm{b}}$ \\
\hline $\mathrm{DMRT}_{0,05}$ & & $2=0,39$ & $3=0,40$ & $4=0,42$ & $5=0,42$ & $6=0,43$ & $7=0,44$ & $8=0,44$ & $9=0,44$ \\
\hline $\begin{array}{l}\text { Kadar } \\
\text { Protein } \\
(\%)\end{array}$ & $38,76^{\text {cde }}$ & $37,71^{\mathrm{de}}$ & $37,28^{\mathrm{e}}$ & $41,13^{b c}$ & $43,32^{\mathrm{ab}}$ & $45,69^{\mathrm{a}}$ & $32,40^{\mathrm{f}}$ & $40,36^{\mathrm{cd}}$ & $40,84^{b c}$ \\
\hline $\mathrm{DMRT}_{0,05}$ & & $2=2,37$ & $3=2,49$ & $4=2,56$ & $5=2,61$ & $6=2,65$ & $7=2,68$ & $8=2,70$ & $9=2,72$ \\
\hline
\end{tabular}

Keterangan: Angka-angka yang diikuti oleh notasi huruf yang sama menunjukkan pengaruh tidak nyata, pada taraf kepercayaan $95 \%(\alpha=0,05)$

\section{Kadar air}

Rerata pengaruh lama perendaman terhadap kadar air pokea asap pada perlakuan T1 (perendaman 5 menit) sebesar 9,34\%, T2 (perendaman 10 menit) sebesar 9,39\% dan T3 (perendaman 15 menit) sebesar 9,31\%. Hasil analisis ragam perlakuan lama perendaman diperoleh tidak berpengaruh nyata sebagaimana pada Tabel 2. Adapun rerata nilai kadar air terhadap konsentrasi asap pada perlakuan N1 (konsentrasi 2\%) sebesar 9,53\%, N2 (konsentrasi 4\%) sebesar 9,29\% dan N3 (konsentrasi 6\%) sebesar 9,22\%. Hasil analisis ragam kadar air pada perlakuan konsentrasi asap cair diperoleh memberikan pengaruh nyata sebagaimana pada Tabel 2 .

Perlakuan interaksi lama perendaman dan konsentrasi asap cair terhadap uji kadar air pokea asap memeberikan pengaruh sangat nyata Rerata kadar air tertinggi pada perlakuan T3N1 (perendaman 15 menit dan konsentrasi $2 \%$ ) dengan rerata nilai sebesar 9,91\% dan hasil uji kadar air terendah pada perlakuan T2N3 (perendaman 10 menit dan konsentrasi
$6 \%$ ) dengan rerata nilai sebesar $8,79 \%$ sebagaimana pada Tabel 3:

Menurunnya kadar air pokea asap disebabkan oleh larutan asap cair meresap ke dalam daging pokea, sehingga air bebas di dalam daging pokea akan terdesak keluar. Dengan demikian, jumlah air bebas di dalam daging pokea menjadi berkurang. Jumlah asap cair yang meresap ke dalam daging pokea. Berdasarkan penjelasan tersebut, maka dapat dikatakan bahwa makin tinggi konsentrasi asap cair yang digunakan untuk merendam daging pokea, maka akan semakin turun kadar air dalam daging pokea. Hal ini sesuai dengan pendapat Kasmadiharja (2008),menyatakan kenaikan nilai kadar airdisebabkan oleh meningkatnya lajurespirasi dan pembentukan air bebaspada bahan oleh mikroba.

\section{Kadar Protein}

Rerata pengaruh lama perendaman terhadap kadar protein pokea asap pada perlakuan T1 (perendaman 5 menit) sebesar 37,91\%, T2 (perendaman 10 menit) sebesar 43,38\% dan T3 (perendaman 15 menit) sebesar $37,87 \%$. Hasil analisis ragam 
perlakuan lama perendaman diperoleh memberikan pengaruh sangat nyata sebagaimana pada Tabel 2. Adapun rerata konsentrasi pokea asap terhadap kadar protein pada perlakuan N1 (konsentrasi 2\%) sebesar 37,43\%, N2 (konsentrasi 4\%) sebesar 40,46\% dan N3 (konsentrasi 6\%) sebesar 41,27\%. Hasil analisis ragam kadar protein pada perlakuan konsentrasi asap cair memberikan pengaruh sangat nyata sebagaimana pada Tabel 2:

Perlakuan interaksi lama perendaman dan konsentrasi asap cair terhadap uji kadar protein pokea asap diperolehmemberikan pengaruh sangat nyata. Rerata nilai tertinggi pada perlakuan T2N3 (perendaman 10 menit dan konsentrasi 6\%) dengan rerata nilai sebesar 45,69\% dan hasil uji kadar protein terendah pada perlakuan T3N1 (perendaman 15 menit dan konsentrasi $2 \%$ ) dengan rerata nilai sebesar $32,40 \%$ sebagaimana pada Tabel 3.

Hal ini diduga terjadi akibat pengurangan air dan penggumpalan protein dalam daging. Hal ini juga sesuai dengan pernyataan Winarno (1991) bahwa dengan berkurangnya kadar air maka akan meningkatkan kadar protein. Dengan adanya pemanasan akan menyebabkan perubahan struktur protein atau biasa disebut denaturasi protein. Winarno (1991) menyatakan bahwa kadar air suatu bahan berbanding terbalik dengan kadar proteinnya. Hal tersebut didukung oleh pernyataan Swastawati et al. (2012) yang menyatakan bahwa kadar protein dapat menurun karena adanya proses pengolahan, dengan terjadinya denaturasi protein selama pemanasan.

\section{Hasil Uji Senyawa PAH}

Salah satu komponen kimia lain yang terbentuk pada pembuatan asap cair tempurung kelapa adalah Polycyclic Aromatic Hydrocarbons (PAH) sebagaimana yang ditunjukkan pada Tabel 4.

Tabel 4. Senyawa Polycyclic Aromatic Hydrocarbons (PAH) pada pokea asap

\begin{tabular}{clccc}
\hline \multirow{2}{*}{ No } & \multirow{2}{*}{ Parameter uji } & \multicolumn{3}{c}{ Kombinasi Perbandingan Pokea Asap (mg/kg) } \\
\cline { 3 - 5 } & & T3N1 & T3N2 & T3N3 \\
\hline 1 & Napthalene & 0,94 & $<0,98$ & $<0,98$ \\
2 & Acenapthelene & 7,41 & 10,69 & 7,44 \\
3 & phenantherene & 3,31 & 12,90 & 4,07 \\
4 & pyrene & 3,17 & 8,53 & 4,25 \\
5 & Benzo(a)pyrene & 2,47 & 5,46 & 3,84 \\
6 & Benzo(a)antracene & 20,1 & 38,59 & 25,24 \\
\hline
\end{tabular}

Keterangan : T1 (Perendaman 5 menit, T2 (Perendaman 10 menit), T3 (Perendaman 15 menit), N1 (Konsentrasi asap cair 2\%), N2 (Konsentrasi asap cair 4\%), N3 (Konsentrasi asap cair 6\%)

Tinggginya kandungan benzo(a)pyrene pada perlakuan $\mathrm{T} 3 \mathrm{~N} 2$ diduga dipengaruhi oleh tingginya kadar lemak yang dimilikinya. Jumlah $P A H$ yang terbentuk selama pengolahan juga tergantung pada kandungan lemak. Lemak yang meleleh dan jatuh pada bahan bakar yang panas akan menyebabkan terjadinya pirolisis lemak yang dapat menghasilkan $P A H$ yang menguap dan tersimpan pada permukaan makanan (Simko, 2002). Menurut Ghazali et al. (2014), pembentukan senyawa $P A H$ berasal dari panas yang tinggi dan dari lemak yang menetes selama proses pembakaran dan pemanggangan. 


\section{KESIMPULAN}

Pokea asap terhadap lama perendaman, konsentrasi asap cair maupuninteraksilama perendaman dan konsentrasi asap cair terhadap organoleptik rupa, bau, tekstur, rasa, kadar air dan kadar protein berpengaruh sangat nyata. Kadar benzo(a)pyrene yang didapatkanpada penelitian ini lebih tinggi dari standar batas penerimaan benzo(a)pyrene pada makanan yaitu 2,47 ppm.

\section{DAFTAR PUSTAKA}

Ayudiarti LD, Sari NR. 2010. Asap Cair dan Aplikasinya Pada Produk Perikanan. Squalen. 5(3).

Bahtiar. 2005. Kajian populasi pokea (Batissa violacea celebensis Martens, 1897) di Sungai Pohara Kendari Sulawesi Tenggara [Tesis]. Bogor: Program Pascasarjana, Institut Pertanian Bogor.

Clucas IJ, Ward AR. (1996). Fisheries Development: A Guide to Handling Preservation, Processing and Quality. Natural Resources Institute. United Kingdom.

Darmadji, Purnomo, Trijuana. 2006. Proses Pemurnian Asap Cair dan Simulasi Akumulasi Kadar Benzopyren pada Proses Perendaman Ikan. Majalah Ilmu dan Teknologi Pertanian. Vol.XXVI, No.2 Th. 2006.

Fellow JP. 2000. Food Processing Technology Principle and Practice. Second Editon. Wood Head Publishing Limited dad CRC Press. Boca Raton, Chambridge.

Ghazali RF, Swastawati F, Romadhon. 2014. Analisa Tingkat Keamanan Ikan Manyung (Arius thalassinus) Asap Yang Diolah Dengan Metode Pengasapan Berbeda. Jurnal
Pengolahan dan Bioteknologi Hasil Perikanan.

Girard JP, 1992. Smoking. In: Technology of Meat and Meat Products (translated by Bernard Hemmings and A.T.T., ClermontFerrand). Ellis Horwood. New York. 22 -25.

Goulas AE, Kontaminas MG. 2005. Effect of salting and smokingmethod on the keeping quality of chub mackerel (scomber japonicas): biochemical and sensory attributes. Food Chem 93:511-520.

Halim, Muhamad, Purnama D, Retno Indarti. 2005. Fraksinasi dan Identifikasi Senyawa Volatil Asap Cair Cangkang Sawit. Agritech 25(3): 117-123.

Kasmadiharja, H. 2008. Kajian Penyimpanan Sosis, Naget Ayam dan Daging Ayam Berbumbu dalam Kemasan Polipropilen Rigid. Skripsi. Fakultas Teknologi Pertanian. Institut Pertanian Bogor. Bogor.

Simko, P. 2002. Determination of polycyclic aromatic hydrocarbons in smoked meat products and smoke flavouring food additives. J Chromatograph.

Swastawati, F., Eko S., Bambang, C \& Wahyu, A.J. 2012. Sensory Evaluation and Chemical Charesteric of Smoked Stingray (Dasyatis bleekery) Processed by Using Two Different Liquid Smoke. International Journal of Bioscience, Biochemistry and Biofarmatics. 2(3).

Varlet, Vincent., Carole Prost., Thierry Serot. 2007. Volatile Aldehydes in Smoked Fish: Analysis Methods, Occurrence and Mechanism of 
Formation. Food Chemistry 105:

1536- 1556.

Winarno. 1991. Kimia pangan dan gizi.

PT.Gramedia Pustaka Utama.

Jakarta. 